\title{
The Evolvement of Buddhism in Southern Dynasty and Its Influence on Literati's Mentality
}

\author{
X.H. Li \\ School of literature and Journalism \\ Shandong University \\ Jinan China
}

\begin{abstract}
In order to study the influence of Buddhism, most of the temples and document in china were investigated. The results indicated that Buddhism developed rapidly in Southern dynasty. Along with the translation of Buddhist scriptures, there were lots of theories about Buddhism at that time. The most popular Buddhist theories were Prajna, Sukhavati and Nirvana. All those theories have important influence on Nan dynasty's literati, especially on their mentality. They were quite different from literati of former dynasties: their attitude toward death, work and nature are more broad-minded. All those factors are displayed in their poems.
\end{abstract}

Keyword-the evolvement of buddhism; southern dynasty; literati's mentality

\section{THE EVOLVEMENT OF BUdDHISM IN SOUTHERN DYNASTY}

The development of Buddhism in Southern Dynasty is prosperous. Many emperors and scholars favor Buddhism a lot: they write lots of articles about the doctrine of Buddhism, and they don't agree much with each other. A variety of Buddhist theories appear at that time. But only three of them are most popular, they are Prajna, Sukhavati and Nirvana. Prajna is relatively quieter in Song Dynasty and Qi Dynasty than Nirvana. Nirvana prospers in Liang Dynasty while Prajna boom again in Liang Dynasty and Chen Dynasty, which eventually renaissance in Chen Dynasty[1] .

\section{PRAJNA: EMPTY AND COLOR}

Prajna's theory is mainly about "empty" and "colour". Prajna is divided into seven denominations. Among them, two denominations, respectively represented by Hui Yuan and Daolin Zhi have the most profound influence on literati. Hui Yuan's denomination considers "empty" as the core factor in Buddhism. "Empty" is the beginning of the word and it is the start of everything. Daolin Zhi's denomination thinks that "color" is the key element in Buddhism. "Color" is the symbol of the universe. It is "empty", but not only "empty".

The monk zhao leads Prajnat to the peak. He thinks there is no difference between "empty" and "color". So monks who believe in Prajnat all take the naturte's "colour" as their way to comprehend "empty". They always build their temple in somewhere near nature. This trend also spread to the literati, that is why there are so much literature about nature then. Southern Dynasty's temple poems mostly show landscapes is also affected by this.

\section{A. Sukhavati: Maitreya and MiTuo}

Hui Yuan and Daolin Zhi also have faith in Sukhavati. Sukhavati is the world where Buddha live. Since there are many Buddha, there are also kinds of Sukhavati. In Southern Dynasty the most prevalent is maitreya pure land and MiTuo pure land.

The advocacy of maitreya pure land is Daolin Zhi while Hui Yuan is the supporter of MiTuo pure land. Hui Yuan's MiTuo pure land wins for its simple practice and beautiful story. According to $<$ Amitabha Sutra $>$, Sukhavati is a perfect world with wonderful flowers and music, decorated by all kinds of jewelry. And it is so easy for every one to enter this paradise only by chanting Amitabha's name for seven days[2] .

Hui Yuan's MiTuo-pure-land theory influence lots of literati in Southern Dynasty, many participate in Hui Yuan's white lotus association. Lingyun Xie, the great poet in that era is also much affected by this theory.

In fact, the beautiful realm that MiTuo pure land depicts exit in the real world, they are Buddhist temples. Buddhist temples are built actually according to the specifications of the Buddhist land. This explains why there are so many temples built and so many poem praise temples.

\section{B. Nirvana: Aha and Icchantika People}

The original meaning of Nirvana is the extinguishment of fire and the blow of the wind. In Buddhism, it means the highest state of dharma practice. Daosheng Zhu is the representative of this theory. He believes that men can become Buddha through aha experience and icchantika people can also be Buddha .

His theory encounters fierce opposition, only Lingyun Xie support him at that time. <The great nirvana sutra>'s coming to china eventually proves the validity of his theory. Nirvana focus on the real world, compared with prajna, it is more close to real life, and eventually replace Prajna as the mainstream of social philosophy.

Poets of Southern dynasty are influenced by this theory, which also showed in their temple poems. Nirvana focus on Buddha's nature. Buddha nature is another name of "truth"[3]. So the poems that depict temple's beautiful scenery always turn to the "truth" in the end. Xiao Yan, Lingyun Xie, Xiao Tong are typical representatives.

The evolvement of Buddhism not only embodied the theoretical aspects, but also affected literati's daily life. In Qi Dynasty and Liang Dynasty, Buddhist rules become literati's 
life discipline, for example, Zhou Yong don't eat meat although he is not a mont[4] . Buddhism entered the stage of religious practice from religious beliefs.

\section{THE INFLUENCE OF BUDDHISM ON LITERATI'S MENTALITY}

Buddihism develops so fast in Southern Dynasty. Many literati favor Buddhism a lot. Buddhism has been deeply involved in the ideas and daily life of the literati. Buddhism inevitably has the influence on literati's outlook on life and aesthetic values.

\section{A. See through Life and Death}

Buddhism dilutes the fear of death from different angles. Prajna thinks "empty" is the beginning of the word and it is the start of everything. So life is not important and death is not scared, everything starts from "empty" and will eventually goes to "empty". Sukhavati considers that by chanting Buddha's name can go to pure land after your death. So the pain of life can be endured, death instead becomes a happy thing. Nirvana believes that everyone even icchantika people could become Buddha. Once one turns to be Buddha, he can be neither die or live.

These Buddhist theories make literati more open minded in the face of life and death. They can be more content with their current life and no longer be feared of death's coming under Buddhism's instruction. These are also reflected in their poems. For example Lingyun Xie's < Dying poem> Wang Xun's < The respond of Tongtai temple poem> and Xiao Gang's< Watch Tongtai temple's pagoda poem $>$ all express an ideal that life is not worth to love .And death is not terrible , it is a splendid beginning of another kind of good life[5] . Their poems reveal to the transcendence of life and death. According to <The history of Southern Dynasty $>$, many literati converted to Buddhism before their death to seek comfort, eg. Zhong Rong[4] , the emperor of Liang dynasty[6], Xiaoke Xu[7]. The literati's view of life and death is deeply influenced by Buddhism.

\section{B. Less Attention on Official Career}

$<$ Vimalakirti Sutra $>$ is a widespread classic of Mahayana Buddhism. Since eastern Jin Dynasty, afer translated by Kumarajiva, <Vimalakirti Sutra $>$ is popular among Chinese literati. "The one and only way" dharma has far-reaching impact on literati in Southern Dynasty. "The one and only way" dharma lists 32 couples of these in the world[8] . "In the world" and "out of the word" is just one couple, they have no difference in essence. This view solves a long lingering problem in literati's head that in the world and out of the word is the exactly the same. Vimalakirti's experience also tells them it is possible to become Buddha while enjoying life.Taking "in the world" and "out of the word" as the same will inevitably lead a trend that literati s less attention on official career. In Southern Dynasty, many literati don't answer the government's recruit, like Cizong Lei, Yimin Liu etc[9]. Although some literati are government officials, they pay more attention on "out of the world" things, like Lingyun Xie[10] and Jiang Zong[11]. What is more, some literati in Liang Dynasty and Chen Dynasty persuit Buddhism faith through debauchery enjoyment, like the emperor of Chen Dynasty, Xu
Ling etc[12]. On the whole, literati don’t value official career a lot in Southern Dynasty.

\section{More Love toward Nature}

The kinship between the nature and humane can be found as early as < the book of poetry $>$ era. But at that time depictions of scenery are sporadic and always triggered by scenery itself, not by aesthetic need. Until the emrgence of Lingyun Xie in Southern Dynasty, there are large amount of landscape poems. And Xie's landscape poem is much related to his Buddhism faith.

According to < Nirvana Sutra $>$, Jetavana is built under the standard that neither far or close to the town, beautiful scenery around[13]. Temples after Jetavana all use this as criteria.

Buddhism's emphasis on the nature has great impact on literati. Enjoying the beauty of the landscape become literati's spiritual needs. Just like what Lingyun Xie have said in his< landscape $\mathrm{fu}>$ : "food and clothes are the necessity of life while landscape is the enjoyment of life"[14] . Literati of that time love the nature a lot, there are many brilliant stories between literati and the nature[15].

Buddhism not only bring literati more enjoyment of the scenery, but also andvance their poem to a high grade. Under the influence of Buddhism landscape poetry which takes Buddhism concept as ultimate purport show a beauty of silence and purity. During this period, a large number of famous writers advantaged in landscape poems appear, like Lingyun Xie, Xie Tiao, Shen Yue, Yin Keng, He Xun etc. They hide Buddhist concept in their landscape poem instead of a direct display of it. So their poem is much vivid than landscape poetry written by poets who has great faith in metaphysics.

\section{REFERENCES}

[1] Yongtong Tang. Han Wei Jin Nan Bei Chao fo jiao shi. Beijing: Zhonghua Book Company. pp. 526-620,1983.

[2] Hui Pu. Southern' Dynasty's Buddhism and literature. Beijing: Zhonghua Book Company. pp. 49-51,2002.

[3] Litian Fang. Wei Jin Nan Bei chao fo jiao lun cong. Beijing: Zhonghua Book Company. pp. 172-175,1982.

[4] Zixian Xiao. The history of Southern Dynasty. Beijing: Zhonghua Book Company. pp. 732-734,1972.

[5] Qinli Lu. Xian Qin Han Wei Jin Nan Bei Chao shi. Beijin: Zhonghua Book Company. pp. 1186-1190,1995.

[6] Yanshou Li. The history of Southern Dynasty. Beijing: Zhonghua Book Compny. pp. 1528-1585,1975.

[7] Yanshou Li. The history of Chen Dynasty. Beijing: Zhonghua Book Company. pp. 236-140,1972.

[8] Sheng Dao, Modern translation of Vimalakarti Sutra. Beijing: China Social Science Publishing House.PP101-107,2003.

[9] Huijiao Shi. Gao seng zhuan. Beijing: Zhonghua Book Compny. pp. 213-215,1992.

[10] Shen Yue. The history of Song Dynasty. Beijing: Zhonghua Book Company. pp. 1772-1775,1974.

[11] Shen Yue. The history of Chen Dynasty. Beijing: Zhoghua Book Company. pp. 346-340,1974.

[12] Pu Hui. Southern Dynasty's Buddhism and literature. Beijing: Zhonghua Book Company. pp. 207-214,2002.

[13] Shangzheng Zhang. Research on Chinese Landscape Literature. Shanghai: Acdemic Press. pp. 19-21,1997.

[14] Qinli Lu. Xian Qin Han Wei Jin Nan Bei Chao shi. Beijing: Zhonghua Book Company. pp. 1120-1125,1995.

[15] Sheng Yuan. Liu Chao qing yin. Henan: Henan People's Publishing House. pp.139-141,2000. 